\title{
Concentration of Heavy Metals in Drinking Water from Urban Areas of the Tigray Region, Northern Ethiopia
}

\section{Gebrekidan Mebrahtu* and Samuel Zerabruk}

Department of Chemistry, College of Natural and Computational Sciences, P. O.Box 2035, Mekelle University, Ethiopia (*geb_meb@yahoo.com and samizer2005@yahoo.com)

\begin{abstract}
The study was undertaken to assess the status of drinking water quality in the urban areas of the Tigray region, northern Ethiopia. A total of 106 drinking water samples were collected from 16 densely populated urban areas of the region, viz.: Alamata, Korem, Maichew, Adigudom, AbyiAdi, Hagereselam, Zalambessa, Adigrat, Edagahamus, Firewoini, Wukro, Mekelle, Indaselassie, Axum, Adwa, and Enticho. All the samples were analyzed for six physicochemical parameters such as temperature, conductivity, total dissolved solids (TDS), salinity, $\mathrm{pH}$, and turbidity and ten heavy metals,viz., As, $\mathrm{Cd}, \mathrm{Co}, \mathrm{Cu}, \mathrm{Cr}, \mathrm{Fe}, \mathrm{Mn}, \mathrm{Ni}, \mathrm{Pb}$, and $\mathrm{Zn}$ using standard procedures. The results were compared with other national and international standards. Among the analyzed samples, regarding physicochemical parameters, $84.01 \%$ for electrical conductivity, $47.17 \%$ for TDS and 31.13\% for turbidity show concentrations higher than the WHO (2008) recommended values. More than $93.4 \%$ of the samples were within the United States Environmental Protection Agency (US EPA) admissible $\mathrm{pH}$ limit (6.5-8.5) and all the samples analyzed were within the EU (1998) admissible $\mathrm{pH}$ limit (6.5-9.5). All samples contain manganese and copper within the WHO (2008) maximum admissible limit, but arsenic $(40.3 \%)$, cadmium $(7.46 \%)$, chromium $(64.18 \%)$, iron $(37.31 \%)$, nickel $(7 \%)$, and lead $(29.85 \%)$ crossed the maximum admissible and desirable limits recommended by WHO (2008). The maximum admissible limit of cobalt in drinking water is not mentioned by WHO, but all the samples analyzed were found to comply the New Zealand $(1000 \mu \mathrm{g} / \mathrm{L})$ and US EPA $(100 \mu \mathrm{g} / \mathrm{L})$ maximum admissible limits. Although no guideline is set by WHO (2008) for Zinc level in drinking water, of the samples analyzed, 94.02\% comply the New Zealand standard and 97.01\% comply all the maximum admissible limits referred in the present study. In general, the results of the present study have shown that some of the physico-chemical parameters have shown values higher than the WHO (2008) recommended maximum admissible limits. This is an indication of pollution hazards and weak drinking water treatment practices in the areas, which in turn have important human health implications. This study, therefore, recommends the government and other responsible authorities to take appropriate corrective measures.
\end{abstract}

Key words: Drinking water quality, Heavy metals, Maximum admissible limit, World health organization, Tigray

\section{INTRODUCTION}

Safe drinking water is a human birthright - as much a birthright as clean air. As a matter of fact, in most of the African and Asian countries, even in relatively advanced countries such as India; safe drinking water is not easily available. Of the 6 billion people on earth, more than one billion lack accesses to safe drinking water and, about 2.5 billion do not have access to adequate sanitation services (TWAS, 2002). In addition to these shortcomings, various types of waterborne 
diseases kill on an average more than 6 million children each year i.e. about 20,000 children a day (TWAS, 2002). Water covers 70 percent of the globe's surface, but most is saltwater. Freshwater covers only 3 percent of the earth's surface and much of it lies frozen in the Antarctic and Greenland polar ice. Freshwater that is available for human consumption comes from rivers, lakes and subsurface aquifers. These sources account for only one percent of all water on the earth. Six billion people depend on this supply and a significant portion of the world's population is facing water shortages (Fig.1). Today 31 countries representing 2.8 billion people, including China, India, Kenya, Ethiopia, Nigeria and Peru confront chronic water problems. Within a generation, the world's population will climb to an estimated 8 billion people. Yet, the amount of water will remain the same (Bishnoi and Arora, 2007). The challenge is as clear and compelling as pristine water cascading down a mountain stream: We must find new and equitable ways of saving, using and recycling the water that we have (Atalay et al., 2008).

Besides the shortage, drinking water may be contaminated by different contaminants which have an impact on the health and economic status of the consumers (Anonymous, 1992). Contaminants such as bacteria, viruses, heavy metals, nitrates and salt have found their way into water supplies due to inadequate treatment and disposal of waste (human and livestock), industrial discharges, and over-use of limited water resources (Singh and Mosley, 2003). Even if no sources of anthropogenic contamination exist, natural sources are also equally potential to contribute higher levels of metals and other chemicals that can harm human health. This is highlighted recently in Bangladesh where natural levels of arsenic in groundwater were found to be causing harmful effects on the population (Anawara et al., 2002).

In Ethiopia, the dominant source of drinking water used to supply major urban and rural communities is from wells and springs. Although there are no systematic and comprehensive water quality assessment programs in the country, there are increasing indications of water contamination problems in some parts of the country. The major causes of this contamination could be soil erosion, domestic waste from urban and rural areas and industrial wastes.

So far, no sufficient study has been conducted on heavy metal contamination of drinking water of the Tigray region. For this reason, due emphasis is given to the analysis of these contaminants. Heavy metals normally occurring in nature are not harmful to our environment because they are only present in very small amounts (Sanayei et al., 2009). However, if the levels of these metals are higher than the recommended limits, their roles change to a negative dimension. Human 
beings can be exposed to heavy metal ions through direct and indirect sources like food, drinking water, exposure to industrial activities and traffic (Ghaedi et al., 2005). Drinking water is one of the important sources for heavy metals for humans. Concentration of the heavy metal ions in drinking water are generally at $\mu \mathrm{g} / \mathrm{l}(\mathrm{ppb})$.

The main goal of this paper is to determine the levels/concentration of some of the physicochemical parameters and heavy metals ( $\mathrm{As}, \mathrm{Cd}, \mathrm{Co}, \mathrm{Cu}, \mathrm{Cr}, \mathrm{Fe}, \mathrm{Mn}, \mathrm{Ni}, \mathrm{Pb}$, and $\mathrm{Zn}$ ) in drinking water in different parts of the Tigray region, Northern Ethiopia and, to compare the values with the national and international organization (like WHO) recommended drinking water standards (Table.1).

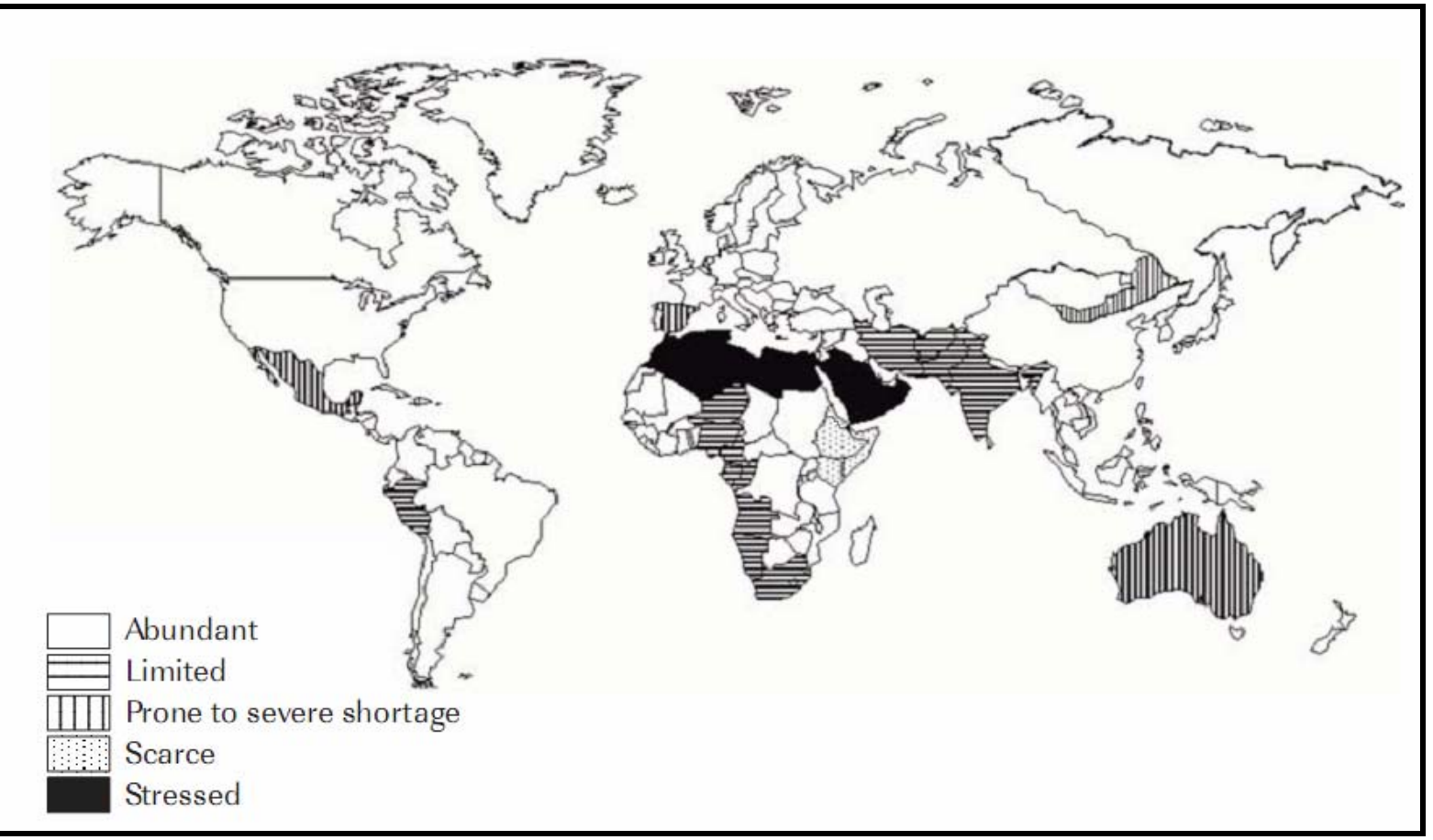

Figure 1. Water availability in different region of the world (TWAS, 2002).

\section{DESCRIPTION OF THE STUDY AREA}

The study was carried out in Tigray National Regional state (Fig. 2). The towns included in the study were Mekelle, Adigudom, Abiyi-Addi, Hagereselam, Adigrat, Enticho, Adwa, Axum, Firewoini,Edagahamus, Inda-Selassie, Korem, Alamata, Maychew, Wukro, Quiha, and Zalambessa,. The region has six administrative zones namely; Western,North west,Eastern, Central, South Estern and Southern. With an estimated area of 50,078.64 square kilometers, this region has an estimated density of 86.15 people per square kilometer. The region 
has diversified agro-ecological zones and niches each with distinct soil, geology, vegetation cover and other natural resources. The climate of the region is generally sub-tropical with an extended dry period of nine to ten months and a maximum effective rainy season of 50-60 days. Considering the rainfall, atmospheric temperature and evapo-transpiration, more than $90 \%$ of the region is categorized as semi-arid.

According to the CSA, as of $2004,53.99 \%$ of the total population had access to safe drinking water, of whom $42.68 \%$ were rural inhabitants and $97.28 \%$ were urban.

Table 1. Drinking water contaminants and maximum admissible limit set by different national and international organizations. (For health risk and aesthetic value)

\begin{tabular}{|c|c|c|c|c|c|c|c|c|c|c|c|c|c|c|}
\hline & \multirow{2}{*}{$\begin{array}{l}E C \\
(\mu S / \mathrm{cm})\end{array}$} & \multirow{2}{*}{$\begin{array}{l}T D S \\
(m g / L)\end{array}$} & \multirow[t]{2}{*}{$p H$} & \multirow{2}{*}{$\begin{array}{l}\text { Turbidity } \\
\text { (NTU) }\end{array}$} & \multicolumn{10}{|c|}{ Heavy Metals $(\mu \mathrm{g} / L)$} \\
\hline & & & & & $A s$ & $C d$ & Co & $C r$ & $C u$ & $\mathrm{Fe}$ & $M n$ & $\mathrm{Ni}$ & $P b$ & $Z n$ \\
\hline $\begin{array}{l}\text { USEPA, } \\
2008\end{array}$ & $\mathrm{NM}^{*}$ & 500 & $\begin{array}{l}6.5 \\
8.5 \\
\end{array}$ & $0.5-1$ & 10 & 5 & 100 & 100 & 1300 & 300 & 50 & 100 & 15 & 5000 \\
\hline EU, 1998 & 2500 & NM & $\begin{array}{l}6.5- \\
9.5\end{array}$ & NM & 10 & 5 & NM & 50 & 2000 & 200 & 50 & 20 & 10 & NM \\
\hline $\begin{array}{l}\text { WHO, } \\
2008\end{array}$ & 250 & $\mathrm{NGL}^{* *}$ & $\mathrm{NGL}^{* *}$ & $\mathrm{NGL}^{\mathrm{a}}$ & 10 & 3 & NM & 50 & 2000 & NGL $^{* * *}$ & 400 & 70 & 10 & $\begin{array}{l}\text { NGL* } \\
*\end{array}$ \\
\hline $\begin{array}{l}\text { Iranian, } \\
1997\end{array}$ & NM & 500 & $\begin{array}{l}6.5 \\
8.5 \\
\end{array}$ & 25 & 50 & 10 & NM & 50 & 1000 & 1000 & 500 & $\mathrm{NM}$ & 50 & NM \\
\hline $\begin{array}{l}\text { Australian, } \\
1996\end{array}$ & NM & $500^{c}$ & $\begin{array}{l}6.5 \\
8.5\end{array}$ & 5.0 & 7 & 2 & NM & $50^{c}$ & 2000 & $300^{c}$ & 500 & 20 & 10 & $3000^{b}$ \\
\hline $\begin{array}{l}\text { Indian, } \\
2005\end{array}$ & NG & 1500 & $\begin{array}{l}6.5- \\
9.2\end{array}$ & 10 & 50 & 10 & NM & $50^{\mathrm{c}}$ & 1500 & 300 & 100 & 20 & 100 & 5000 \\
\hline $\begin{array}{l}\text { New } \\
\text { Zealand, } \\
2008 \\
\end{array}$ & NM & 1000 & $\begin{array}{l}7.0- \\
8.5\end{array}$ & 2.5 & 10 & 4 & 1000 & 50 & 2000 & 200 & 400 & 80 & 10 & 1500 \\
\hline
\end{tabular}

*NM $=$ Not mentioned,

** NGL $=$ No Guideline, because it occurs in drinking-water at concentrations well below those at which toxic effects may occur,

*** No Guideline, because it is not of health concern at concentrations normally observed in drinking water, but may affect the acceptability of water at concentration above $300 \mu \mathrm{g} / \mathrm{L}$,

$\mathrm{NGL}^{\mathrm{a}}$ No Guideline but desirable less than 5 NTU,

${ }^{\mathrm{b}}$ based on quality (Aesthetic) not safety (Health risk),

${ }^{c}$ Chromium as $\mathrm{Cr}^{+6}$ not total $\mathrm{Cr}$.

\section{METHODOLOGY}

\subsection{Drinking Water Sampling}

A total of 106 ground drinking water samples were collected from sixteen densely populated urban areas of the region: Alamata, Korem, Maichew, Adigudom, Abyi-Adi, Hagereselam, Zalambessa, Adigrat, Edagahamus, Firewoini, Wukro, Mekelle, Indasilase, Axum, Adwa, and Enticho (Fig. 2). All the samples are taken from chlorine treated ground water sources. The drinking water samples were collected in prewashed (with detergent, dilute $\mathrm{HNO}_{3}$, doubly de- 
ionized distilled water respectively) double caped polyethylene bottles from February to May 2010. In the field, the sampling bottles and caps were rinsed three times with the water to be sampled prior to sampling. Most of the samples were obtained directly from the tap after allowing the water to run for at least 5 min so as to stabilise the variation in EC and Temperature (Reimann et al., 2003). Then, the samples were acidified to $1 \%$ with nitric acid and were stored in $500 \mathrm{~mL}$ double caped polyethylene bottles. The samples were subsequently stored at $4{ }^{0} \mathrm{C}$ for as short a time as possible before analysis to minimize changes of the physicochemical characteristics of the metals (Tuzen and Soylak, 2006). As this study is supposed to reflect the quality of the water 'as drunk', the samples were not filtered (Reiman et al., 1996).

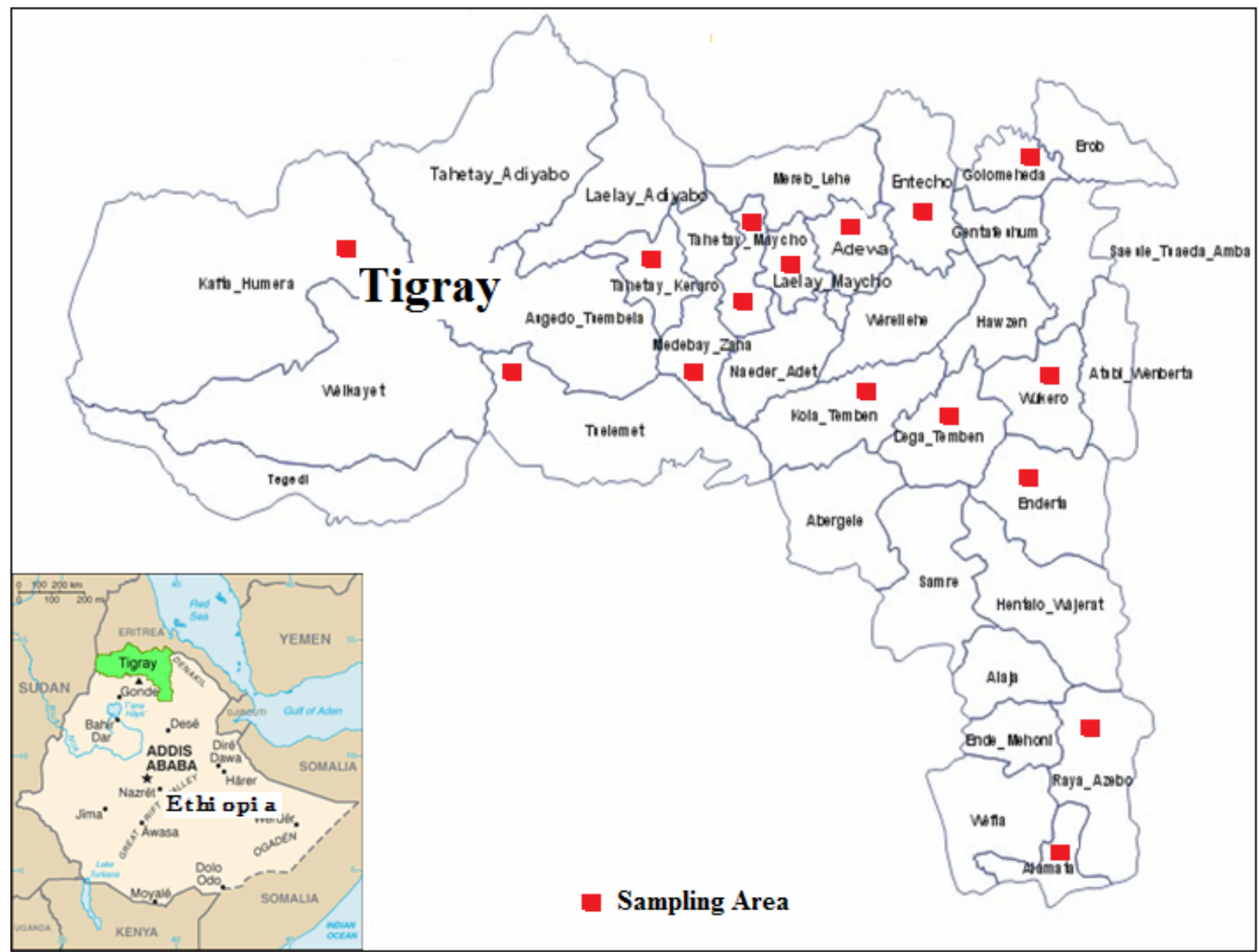

Figure 2. Location of the sampling areas in Tigray region, Northern Ethiopia.

\subsection{Sample Analysis}

Physical parameters like temperature, conductivity, total dissolved solids and salinity of the 
samples were measured at the sampling sites using Jenway 4150, portable conductivity meter. $\mathrm{pH}$ was also recorded at the sampling sites using Hach, HQ11d Portable pH Meter. Turbidity of the samples was measured at aquatic chemistry laboratory of Mekelle University using Hach, 2100Q Turbidimeter. Heavy metals ( $\mathrm{As}, \mathrm{Cd}, \mathrm{Co}, \mathrm{Cu}, \mathrm{Cr}, \mathrm{Fe}, \mathrm{Mn}, \mathrm{Ni}, \mathrm{Pb}$ and $\mathrm{Zn}$ ) analysis was done at analytical laboratory of Ezana Mining Development P.L.C. using AA240FC, Varian instruments, Fast Sequential AAS Australia with instrument working condition mentioned in table 2. Analytical grade chemicals $\left(\mathrm{HNO}_{3}\right.$, Sigma chemicals, Australia and standard heavy metal solutions, Varian instruments, Australia) after preserving at $4{ }^{\circ} \mathrm{C}$ for short period of time.

Table 2. Instrument working conditions.

\begin{tabular}{|l|c|c|c|c|c|c|c|c|c|c|}
\hline Element & $\boldsymbol{A s}$ & $\boldsymbol{C d}$ & $\boldsymbol{C o}$ & $\boldsymbol{C u}$ & $\boldsymbol{C r}$ & $\boldsymbol{F e}$ & $\boldsymbol{M n}$ & $\boldsymbol{N i}$ & $\boldsymbol{P b}$ & $\boldsymbol{Z n}$ \\
\hline Lamp current $(\mathrm{mA})$ & 10 & 4 & 7 & 4 & 7 & 5 & 5 & 4 & 5 & 5 \\
\hline Fuel & $\mathrm{C}_{2} \mathrm{H}_{2}$ & $\mathrm{C}_{2} \mathrm{H}_{2}$ & $\mathrm{C}_{2} \mathrm{H}_{2}$ & $\mathrm{C}_{2} \mathrm{H}_{2}$ & $\mathrm{C}_{2} \mathrm{H}_{2}$ & $\mathrm{C}_{2} \mathrm{H}_{2}$ & $\mathrm{C}_{2} \mathrm{H}_{2}$ & $\mathrm{C}_{2} \mathrm{H}_{2}$ & $\mathrm{C}_{2} \mathrm{H}_{2}$ & $\mathrm{C}_{2} \mathrm{H}_{2}$ \\
\hline Support & $\mathrm{N}_{2} \mathrm{O}$ & Air & Air & Air & $\mathrm{N}_{2} \mathrm{O}$ & Air & Air & Air & $\mathrm{N}_{2} \mathrm{O}$ & Air \\
\hline Wave length (nm) & 197.7 & 228.8 & 240.7 & 324.7 & 357.9 & 248.3 & 275.9 & 232.0 & 217.0 & 213.9 \\
\hline Slit width (nm) & 0.5 & 0.5 & 0.2 & 0.5 & 0.2 & 0.2 & 0.2 & 0.2 & 1.0 & 1.0 \\
\hline
\end{tabular}

Note: Flame used was reducing (red cone) for As, Cr and oxidizing for others.

\section{RESULTS AND DISCUSSION}

The range and the average value, $\bar{X} \pm 1 \mathrm{SD}$, of the physical parameters including temperature, conductivity, TDS, salinity, $\mathrm{pH}$ and turbidity of the drinking water samples are given in Table 3. Temperature of the samples was in the range of 11.8 to $27.7^{\circ} \mathrm{C}$, with minimum value (11.8) from Hagereselam and maximum from Alamata. Electrical conductivity (EC) which is a measure of water's ability to conduct an electric current is related to the amount of dissolved minerals in water, but it does not give an indication of which element is present but higher value of EC is a good indicator of the presence of contaminants such as sodium, potassium, chloride or sulphate (Orebiyi et al., 2010). Analysis of the results show that all the samples from Alamata, Korem, Maichew, and Abiyi-Addi (15.09\% of the samples) have EC value less than the WHO (2008) (Table 1) maximum admissible limit; while the rest of the samples (84.01\%) have EC values more than the limit. The range of $\mathrm{EC}$ of the samples was from 44.1 to $2130 \mu \mathrm{S} / \mathrm{cm}$, with minimum (44.1) from Abiyi-Addi and maximum (2130) from Mekelle Drinking water samples. Very high values of EC with mean value of $1035,1663.09$ and $1793.6 \mathrm{t} \mu \mathrm{S} / \mathrm{cm}$ was recorded for samples collected from Indasilase, Mekelle and Axum respectively. 
Table 3. Level of some physical parameters for drinking water samples from urban areas of Tigray region, Ethiopia.

\begin{tabular}{|c|c|c|c|c|c|c|c|c|c|c|c|c|}
\hline \multirow[t]{2}{*}{$\begin{array}{l}\text { Sampling } \\
\text { location }\end{array}$} & \multicolumn{2}{|c|}{$\begin{array}{l}\text { Temperature } \\
\left({ }^{\circ} \mathrm{C}\right)\end{array}$} & \multicolumn{2}{|c|}{$\begin{array}{l}\text { Conductivity, } \\
(\mu \mathrm{S} / \mathrm{cm})\end{array}$} & \multicolumn{2}{|l|}{$\begin{array}{l}T D S \\
(m g / L)\end{array}$} & \multicolumn{2}{|c|}{ Salinity $(\mathrm{g} / \mathrm{L})$} & \multicolumn{2}{|l|}{$p H$} & \multicolumn{2}{|c|}{$\begin{array}{l}\text { Turbidity, } \\
\text { NTU }\end{array}$} \\
\hline & $\bar{X} \pm S D$ & Range & $\bar{X} \pm S D$ & Range & $\bar{X} \pm \boldsymbol{S D}$ & Range & $\bar{X} \pm S D$ & Range & $\begin{array}{l}\bar{X} \pm \\
S D\end{array}$ & Range & $e \overline{\mathrm{X}} \pm \boldsymbol{S D}$ & Range \\
\hline Alamata & $\begin{array}{l}26.17 \pm \\
1.46\end{array}$ & $\begin{array}{l}24.80- \\
27.7\end{array}$ & $\begin{array}{l}151.33 \pm \\
6.66\end{array}$ & $\begin{array}{l}147- \\
159\end{array}$ & $\begin{array}{l}76.33 \pm \\
3.21\end{array}$ & $74-80$ & $\begin{array}{l}0.50 \pm \\
0.00\end{array}$ & 0.5 & $\begin{array}{l}7.43 \pm \\
0.41\end{array}$ & $\begin{array}{l}7.02- \\
7.85\end{array}$ & $\begin{array}{l}7.92 \pm \\
0.98\end{array}$ & $\begin{array}{l}6.80- \\
8.55\end{array}$ \\
\hline Korem & \begin{tabular}{|l|}
$21.10 \pm$ \\
1.87
\end{tabular} & $\begin{array}{l}19.00- \\
22.6\end{array}$ & $\begin{array}{l}87.37 \pm \\
2.32\end{array}$ & \begin{tabular}{|l|}
$84.70-$ \\
89.00
\end{tabular} & $\begin{array}{l}44.00 \pm \\
1.00\end{array}$ & $\begin{array}{l}43.00 \\
45.00 \\
\end{array}$ & $\begin{array}{l}-0.50 \pm \\
0.00 \\
\end{array}$ & 0.5 & $\begin{array}{l}7.48 \pm \\
0.50 \\
\end{array}$ & $\begin{array}{l}6.92- \\
7.92 \\
\end{array}$ & $\begin{array}{l}4.61 \pm \\
0.50 \\
\end{array}$ & $\begin{array}{l}4.12- \\
5.14 \\
\end{array}$ \\
\hline Maichew & $\begin{array}{l}21.77 \pm \\
0.68\end{array}$ & $\begin{array}{l}21- \\
22.3\end{array}$ & $\begin{array}{l}107.20 \pm \\
32\end{array}$ & $\begin{array}{l}105.7- \\
108.2\end{array}$ & $\begin{array}{l}53.67 \pm \\
0.58\end{array}$ & $53-54$ & $\begin{array}{l}0.50 \pm \\
0.00\end{array}$ & 0.5 & $\begin{array}{l}8.48 \pm \\
0.14\end{array}$ & $\begin{array}{l}8.32- \\
8.61\end{array}$ & $\begin{array}{l}7.01 \pm \\
1.06\end{array}$ & $\begin{array}{l}5.92- \\
8.03\end{array}$ \\
\hline Adigudom & \begin{tabular}{|l}
$22.50 \pm$ \\
1.09
\end{tabular} & $\begin{array}{l}21.7- \\
23.7\end{array}$ & $\begin{array}{l}261.33 \pm \\
0.58\end{array}$ & $\begin{array}{l}261- \\
262 \\
\end{array}$ & \begin{tabular}{|l}
$134.67 \pm$ \\
3.51 \\
\end{tabular} & $131-13$ & $\begin{array}{l}80.50 \pm \\
0.00\end{array}$ & 0.5 & $\begin{array}{l}7.99 \pm \\
0.49 \\
\end{array}$ & $\begin{array}{l}7.61- \\
8.55 \\
\end{array}$ & $\begin{array}{l}6.21 \pm \\
0.59 \\
\end{array}$ & $\begin{array}{l}5.73- \\
6.87 \\
\end{array}$ \\
\hline Abyi- Adi & $\begin{array}{l}23.74 \pm \\
2.33\end{array}$ & $\begin{array}{l}19.7- \\
25.7\end{array}$ & $50.2 \pm 4.43$ & $\begin{array}{l}344.1- \\
55.9 \\
\end{array}$ & \begin{tabular}{|l}
$25.8 \pm$ \\
3.11 \\
\end{tabular} & $21-29$ & $\begin{array}{l}0.5 \pm \\
0.00\end{array}$ & 0.5 & \begin{tabular}{|l}
$7.97 \pm$ \\
0.53 \\
\end{tabular} & \begin{tabular}{|l|}
$7.34-$ \\
8.54 \\
\end{tabular} & \begin{tabular}{|l}
$3.94 \pm$ \\
0.55 \\
\end{tabular} & $\begin{array}{l}3.41- \\
4.81\end{array}$ \\
\hline Hagereselam & $\begin{array}{l}14.67 \pm \\
3.00\end{array}$ & $\begin{array}{l}11.8- \\
17.8\end{array}$ & $\begin{array}{l}586 \pm \\
18.73\end{array}$ & $\begin{array}{l}571- \\
607\end{array}$ & \begin{tabular}{|l}
$349.67 \pm$ \\
13.87
\end{tabular} & $338-36$ & $55 \begin{array}{l}0.5 \pm \\
0.00\end{array}$ & 0.5 & $\begin{array}{l}8.19 \pm \\
0.74\end{array}$ & $\begin{array}{l}7.66- \\
9.04\end{array}$ & $\begin{array}{l}3.34 \pm \\
0.62\end{array}$ & $\begin{array}{l}2.63- \\
3.79\end{array}$ \\
\hline Zalambessa & $\begin{array}{l}16.37 \pm \\
0.25\end{array}$ & $\begin{array}{l}16.1- \\
16.6\end{array}$ & $503 \pm 6.08$ & $\begin{array}{l}499- \\
510\end{array}$ & $\begin{array}{l}305.33 \pm \\
8.50\end{array}$ & $299-31$ & $\begin{array}{l}50.5 \pm \\
0.00\end{array}$ & 0.5 & $\begin{array}{l}7.54 \pm \\
0.11 \\
\end{array}$ & $\begin{array}{l}7.47- \\
7.67 \\
\end{array}$ & $\begin{array}{l}7.58 \pm \\
2.00\end{array}$ & $\begin{array}{l}5.56- \\
9.78\end{array}$ \\
\hline Adigrat & $\begin{array}{l}17.30 \pm \\
2.61\end{array}$ & $\begin{array}{l}13.6- \\
20\end{array}$ & $\begin{array}{l}768.33 \pm \\
122.10\end{array}$ & $\begin{array}{l}532- \\
1013\end{array}$ & $\begin{array}{l}469.33 \pm \\
25.78\end{array}$ & $422-51$ & $\begin{array}{l}60.58 \pm \\
0.06\end{array}$ & $0.5-0.7$ & $\begin{array}{l}7.67 \pm \\
0.41\end{array}$ & $\begin{array}{l}7.19- \\
8.63\end{array}$ & $\begin{array}{l}4.31 \pm \\
2.61\end{array}$ & $\begin{array}{l}1.11- \\
8.83\end{array}$ \\
\hline Edagahamus & $\begin{array}{l}15.40 \pm \\
1.98\end{array}$ & $\begin{array}{l}14- \\
16.8 \\
\end{array}$ & $\begin{array}{l}115.25 \pm \\
8.13\end{array}$ & $\begin{array}{l}109.50- \\
121.00\end{array}$ & $\begin{array}{l}71.40 \pm \\
9.90\end{array}$ & $\begin{array}{l}64.4 \\
78.4 \\
\end{array}$ & $\begin{array}{r}-0.4 \pm \\
0.00\end{array}$ & 0.4 & $\begin{array}{l}7.79 \pm \\
0.37 \\
\end{array}$ & $\begin{array}{l}7.52- \\
8.05\end{array}$ & $\begin{array}{l}1.81 \pm \\
1.48 \\
\end{array}$ & $\begin{array}{l}0.77- \\
2.867\end{array}$ \\
\hline Firewoini & $\begin{array}{l}15.95 \pm \\
2.33\end{array}$ & $\begin{array}{l}14 .- \\
17.6\end{array}$ & $\begin{array}{l}425.50 \pm \\
9.19\end{array}$ & $\begin{array}{l}419- \\
432\end{array}$ & $\begin{array}{l}257.50 \pm \\
6.36\end{array}$ & $253-26$ & $2 \begin{array}{l}0.50 \pm \\
0.00\end{array}$ & 0.5 & $\begin{array}{l}8.2 \pm \\
0.06\end{array}$ & $\begin{array}{l}8.24- \\
8.32\end{array}$ & $\begin{array}{l}6.17 \pm \\
2.95\end{array}$ & 8.32 \\
\hline Wukro & $\begin{array}{l}17.21 \pm \\
2.019\end{array}$ & $\begin{array}{l}14.3- \\
20.00\end{array}$ & $\begin{array}{l}735.50 \pm \\
166.20 \\
\end{array}$ & $\begin{array}{l}567- \\
997\end{array}$ & $\begin{array}{l}439.5 \pm \\
100.19 \\
\end{array}$ & $339-59$ & $\begin{array}{l}770.56 \pm \\
0.07\end{array}$ & $0.5-0.7$ & $\begin{array}{l}7.81 \pm \\
0.58 \\
\end{array}$ & $\begin{array}{l}7.04- \\
8.82 \\
\end{array}$ & $\begin{array}{l}3.86 \pm \\
0.52\end{array}$ & $\begin{array}{l}2.98- \\
4.71\end{array}$ \\
\hline Mekelle & $17.78 \pm 1.64$ & $\begin{array}{l}14.6- \\
21.2\end{array}$ & $\begin{array}{l}1663.09 \pm \\
240.21\end{array}$ & $\begin{array}{l}1172- \\
2130\end{array}$ & \begin{tabular}{|l}
$999.72 \pm$ \\
145.24
\end{tabular} & $\begin{array}{l}698 \\
1288 \\
\end{array}$ & $\begin{array}{l}-0.90 \pm \\
0.09\end{array}$ & $0.7-1.1$ & $\begin{array}{l}7.86 \pm \\
0.24\end{array}$ & $\begin{array}{l}7.44- \\
8.36\end{array}$ & $\begin{array}{l}7.09 \pm \\
5.17\end{array}$ & $\begin{array}{l}0.504- \\
27.42\end{array}$ \\
\hline IndaSelassie & \begin{tabular}{|l|}
$16.94 \pm$ \\
1.68 \\
\end{tabular} & $\begin{array}{l}14.6- \\
19.1 \\
\end{array}$ & \begin{tabular}{|l}
$1035 \pm$ \\
104.41 \\
\end{tabular} & $\begin{array}{l}860- \\
1170\end{array}$ & $\begin{array}{l}665.4 \pm \\
163.32 \\
\end{array}$ & \begin{tabular}{|l}
515 \\
1095 \\
\end{tabular} & $\begin{array}{l}-0.66 \pm \\
0.05\end{array}$ & $0.6-0.7$ & $\begin{array}{l}7.42 \pm \\
0.24 \\
\end{array}$ & $\begin{array}{l}7.08- \\
7.72\end{array}$ & $\begin{array}{l}3.13 \pm \\
2.11\end{array}$ & $\begin{array}{l}0.31- \\
7.16\end{array}$ \\
\hline Axum & $16.9 \pm 1.20$ & $\begin{array}{l}15- \\
18.9\end{array}$ & $\begin{array}{l}1793.67 \pm \\
146.84\end{array}$ & $\begin{array}{l}1493- \\
2050\end{array}$ & $\begin{array}{l}1004.75 \pm \\
293.46\end{array}$ & $\begin{array}{l}435 \\
1593\end{array}$ & $\begin{array}{c}-0.88 \pm \\
0.18\end{array}$ & $0.6-1.3$ & $\begin{array}{l}6.99 \pm \\
0.14 \\
\end{array}$ & $\begin{array}{l}6.80- \\
7.35\end{array}$ & \begin{tabular}{|l}
$2.79 \pm$ \\
1.09 \\
\end{tabular} & $\begin{array}{l}1.42- \\
5.26\end{array}$ \\
\hline Adwa & \begin{tabular}{|l|}
$19.83 \pm$ \\
1.03
\end{tabular} & $\begin{array}{l}18.4- \\
21.6\end{array}$ & $\begin{array}{l}366.80 \pm \\
3.26\end{array}$ & $\begin{array}{l}362- \\
371\end{array}$ & $\begin{array}{l}219.50 \pm \\
2.22\end{array}$ & $217-22$ & $\begin{array}{l}240.40 \pm \\
0.00\end{array}$ & 0.4 & $\begin{array}{l}7.63 \pm \\
0.22 \\
\end{array}$ & $\begin{array}{l}7.13- \\
7.89\end{array}$ & $\begin{array}{l}2.52 \pm \\
0.53 \\
\end{array}$ & $\begin{array}{l}1.52- \\
3.14\end{array}$ \\
\hline Enticho & $\begin{array}{l}20.98 \pm \\
0.71\end{array}$ & \begin{tabular}{|l|}
$20.1-$ \\
21.7 \\
\end{tabular} & $\begin{array}{l}817.25 \pm \\
127.58 \\
\end{array}$ & $\begin{array}{l}675- \\
979 \\
\end{array}$ & $\begin{array}{l}487 \pm \\
87.78 \\
\end{array}$ & $405-59$ & \begin{tabular}{|l}
$0.58 \pm$ \\
0.15 \\
\end{tabular} & $0.4-0.7$ & \begin{tabular}{|l|}
$7.63 \pm$ \\
0.27 \\
\end{tabular} & $\begin{array}{l}7.31- \\
7.93 \\
\end{array}$ & \begin{tabular}{|l}
$1.99 \pm$ \\
0.62 \\
\end{tabular} & $\begin{array}{l}0.99- \\
2.31 \\
\end{array}$ \\
\hline
\end{tabular}

According to WHO (2008), there is no health based limit for TDS in drinking water, as TDS occurs in drinking water at concentrations well below toxic effects may occur, but the palatability of water with TDS level of less than $500 \mathrm{mg} / \mathrm{L}$ is generally considered to be good. Drinking water becomes significantly and increasingly unpalatable at TDS Levels greater than about $1000 \mathrm{mg} / \mathrm{L}$. TDS greater than $1200 \mathrm{mg} / \mathrm{L}$ may be objectionable to consumers and could have impacts for those who need to limit their daily salt intake e.g. Severely hypertensive, diabetic, and renal dialysis patients (London et al., 2005). Of the samples analyzed $47.17 \%$ were found to contain TDS value of greater than $500 \mathrm{mg} / \mathrm{L}$, these were mainly from Axum, Mekelle, 
and Indasilase with Mean TDS value of 1004.75, 999.72 and $665.4 \mathrm{mg} / \mathrm{L}$ respectively. Highest TDS value $(1593 \mathrm{mg} / \mathrm{L})$ was recorded in drinking water sample from Axum and lowest (21 $\mathrm{mg} / \mathrm{L}$ ) from Abyi-Adi.

According to the salinity classification of Rabinove et al., 1958, (Table 4), more than $94.33 \%$ of the samples were found to be non-saline and only $5.67 \%$ were slightly saline. $\mathrm{pH}$ of the samples was between 6.8 (Axum) and 9.04 (Hagereselam) with more than $89 \%$ of the samples' pH laying in the alkaline range. There is no guideline value by $\mathrm{WHO}$ for $\mathrm{pH}$ but $93.4 \%$ of the samples analyzed were within the US EPA admissible limit (6.5-8.5) and all the samples analyzed were within the (EU, 1998) admissible limit (6.5-9.5).

Table 4. Classification of the drinking water samples on the basis of salinity (Rabinove et al., 1958).

\begin{tabular}{|l|l|c|c|c|}
\hline S. No & Description of the drinking water & Salinity (g/L) & No of Samples & Percentage \\
\hline 1 & Non Saline & $<1$ & 100 & $94.33 \%$ \\
\hline 2 & Slightly Saline & $1-3$ & 6 & $5.67 \%$ \\
\hline 3 & Moderately Saline & $3-10$ & 0 & $0.00 \%$ \\
\hline 4 & Very Saline & $>10$ & 0 & $0.00 \%$ \\
\hline
\end{tabular}

Turbidity is a measure of cloudiness of water. It has no health effects. However, turbidity can interfere with disinfection and provide a medium for microbial growth. High turbidity may indicate the presence of disease causing organisms. These organisms include bacteria, viruses, and parasites that can cause symptoms such as nausea, cramps, diarrhea, and associated headaches (Akoto and Adiyiah, 2007). 31.13\% of the samples have turbidity value greater than 5 NTU (Nephelometric Turbidity Units), which is the WHO (2008) maximum desirable limit in drinking water (Table 1) and these were mainly from Mekelle, Adigrat, Zalambessa, Adigudom, Maichew and Alamata. Turbidity value as high as 27.42 NTU was observed in a sample from Mekelle and the lowest, 0.31 from Indaselassie.

Guidelines for the presence of heavy metals in drinking water have been set by different international organizations like US EPA, WHO, European Union commission (Momodu and Anyakora, 2010). Many national organizations like Bureau of Indian Standards (BIS) have also set their own drinking water standards (Table 1). As specified by these organizations there are maximum admissible limits for heavy metals in drinking water.

The concentrations of heavy metals: $\mathrm{As}, \mathrm{Cd}, \mathrm{Co}, \mathrm{Cr}, \mathrm{Cu}, \mathrm{Fe}, \mathrm{Mn}, \mathrm{Ni}, \mathrm{Pb}$, and $\mathrm{Zn}$ in the drinking water samples analyzed are presented in tables 5 and 6 . Highest heavy metal concentration was 
found for Zinc $(3886 \mu \mathrm{g} / \mathrm{L})$ in water sample from Axum. Levels of Iron and Zinc were above the detection limit in all the samples. Copper was the only heavy metal that was below the detection limit in any of the samples.

Table 5. Concentration of heavy metals $\mathrm{As}, \mathrm{Cd}, \mathrm{Co}, \mathrm{Cr}$ and $\mathrm{Cu}(\mu \mathrm{g} / \mathrm{L})$ in drinking water samples from urban areas of Tigray region, Ethiopia

\begin{tabular}{|l|c|c|c|c|c|c|c|c|c|c|}
\hline \multirow{2}{*}{$\begin{array}{l}\text { Sampling } \\
\text { location }\end{array}$} & \multicolumn{2}{|c|}{ As } & \multicolumn{2}{c|}{ Cd } & \multicolumn{2}{c|}{ Co } & \multicolumn{3}{c|}{ Cr } & \multicolumn{2}{c|}{ Cu } \\
\cline { 2 - 14 } & $\overline{\boldsymbol{X}} \pm$ SD & Range & $\overline{\boldsymbol{X}} \pm$ SD & Range & $\overline{\mathbf{X}} \pm$ SD & Range & $\overline{\boldsymbol{X}} \pm$ SD & Range & $\overline{\mathbf{X}} \pm$ SD & Range \\
\hline Alamata & BDL $^{*}$ & - & BDL & - & BDL & - & $108 \pm 10$ & $99-117$ & BDL & - \\
\hline Korem & BDL & - & BDL & - & BDL & - & $97 \pm 6$ & $93-101$ & BDL & - \\
\hline Maichew & BDL & - & BDL & - & BDL & - & $98 \pm 7$ & $93-103$ & BDL & - \\
\hline Adigudom & BDL & - & BDL & - & BDL & - & $104 \pm 8$ & $99-110$ & BDL & - \\
\hline Abyi- Adi & BDL & - & BDL & - & BDL & - & $98 \pm 2$ & $96-101$ & BDL & - \\
\hline Hagereselam & $620 \pm 84$ & $560-680$ & BDL & - & BDL & - & $104 \pm 4$ & $101-108$ & BDL & - \\
\hline Zalambessa & $740 \pm 239$ & $571-910$ & BDL & - & BDL & - & $120 \pm 12$ & $111-128$ & BDL & - \\
\hline Adigrat & BDL & - & BDL & - & BDL & - & $121 \pm 11$ & $106-136$ & BDL & - \\
\hline Edagahamus & BDL & - & BDL & - & $8 \pm 2$ & $6-10$ & $116 \pm 17$ & $104-128$ & BDL & - \\
\hline Firewoini & BDL & - & BDL & - & BDL & - & $107 \pm 20$ & $92-121$ & BDL & - \\
\hline Wukro & BDL & - & BDL & - & BDL & - & $116 \pm 7$ & $106-125$ & BDL & - \\
\hline Mekelle & $395 \pm 60$ & $330-460$ & $17 \pm 2$ & $14-21$ & $18 \pm 7$ & $11-30$ & $146 \pm 9$ & $131-158$ & BDL & - \\
\hline Indasilase & $603 \pm 240$ & $390-1060$ & BDL & - & $16 \pm 8$ & $8-29$ & BDL & - & BDL & - \\
\hline Axum & $520 \pm 154$ & $320-760$ & BDL & - & $27 \pm 6$ & $19-36$ & BDL & - & BDL & - \\
\hline Adwa & $630 \pm 170$ & $450-790$ & BDL & - & $23 \pm 2$ & $22-26$ & BDL & - & BDL & - \\
\hline Enticho & $725 \pm 190$ & $590-860$ & BDL & - & $17 \pm 7$ & $12-22$ & BDL & - & BDL & - \\
\hline
\end{tabular}

$* B D L=$ below detection limit of the method.

Chromium was detected in 12 of the sampling areas followed by arsenic, nickel and lead which were detected in 7 of the sampling sites. Cobalt and manganese were also detected in 6 of the sampling areas while cadmium was detected in only one sampling area.

The Arsenic concentration is found to be a major threat in Hagereselam, Zalambessa, Mekelle, Indasilase, Axum, Adwa and Enticho with highest concentration measured 680, 910, 460, 1060, 760,790 and $860 \mu \mathrm{g} / \mathrm{L}$ respectively. More than $40.3 \%$ of the samples analyzed, were found to contain arsenic level above the WHO recommended value of $10 \mu \mathrm{g} / \mathrm{L}$ (Table. 1).

Cadmium occurs mostly in association with zinc and gets into water from corrosion of zinc coated ("galvanized") pipes and fittings (danamark.com 2008). At higher concentrations, it is known to have a toxic potential. The main sources of cadmium are industrial activities; the metal is widely used in electroplating, pigments, plastics, stabilizers and battery industries (Nassef et al., 2006). Cadmium is highly toxic and responsible for several cases of poisoning through food. Small quantities of cadmium cause adverse changes in the arteries of human kidney. It replaces zinc biochemically and causes high blood pressures, kidney damage etc (Rajappa et al., 2010). It interferes with enzymes and causes a painful disease called Itai-itai. In the present study, 
cadmium is detected in water only from Mekelle area, where Cd value is above the WHO (2008) recommended value $(3 \mu \mathrm{g} / \mathrm{L})$ in $7.46 \%$ of the samples analyzed with mean concentration of 17 $\mu \mathrm{g} / \mathrm{L}$ and varies from 14 to $21 \mu \mathrm{g} / \mathrm{L}$.

Cobalt concentration was found to be below the detection limit in ten of the sampling areas (Alamata, Korem, Maichew, Adigudom, Abyi- Adi, Hagereselam, Zalambessa, Adigrat, Firewoini, Wukro). In the other areas, cobalt concentration ranges from 8 to $36 \mu \mathrm{g} / \mathrm{L}$ with the maximum $(36 \mu \mathrm{g} / \mathrm{L})$ in drinking water sampled from Axum and minimum $(8 \mu \mathrm{g} / \mathrm{L})$ from Indasilase. Though the maximum admissible limit, MAL of cobalt is not mentioned by WHO (2008), all the samples analyzed comply the New Zealand (1000 $\mu \mathrm{g} / \mathrm{L})$ and US EPA (100 $\mu \mathrm{g} / \mathrm{L})$ maximum admissible limits of cobalt in drinking water (Table 1).

Chromium is an essential micronutrient for animals and plants, and is considered as a biological and pollution significant element. Generally the natural content of chromium in drinking water is very low ranging from 10 to $50 \mu \mathrm{g} / \mathrm{L}$ except for the regions with substantial chromium deposits (Jayana et al., 2009). Chromium in excess amounts can be toxic especially in the hexavalent form. Sub chronic and chronic exposure to chromic acid can cause dermatitis and ulceration of the skin. Long-term exposure can cause kidney, liver, circulatory and nerve tissue damages. Chromium often accumulates in aquatic life, adding to the danger of eating fish that may have been exposed to high level of chromium (Hanaa et al., 2000; Pandey et al., 2010). In this study, chromium was not detected in only four of the sampling areas (Indasilase, Axum, Adwa, and Enticho). In the other areas, Chromium level varies from $92 \mu \mathrm{g} / \mathrm{L}$ in Firewoini to $158 \mu \mathrm{g} / \mathrm{L}$ in Mekelle, which are above the WHO (2008) maximum admissible limit of $\mathrm{Cr}$ in drinking water $(50 \mu \mathrm{g} / \mathrm{L})$. Of all the samples analyzed, 64.18\% contain chromium level above WHO (2008) maximum admissible limit with the highest level of chromium recorded for samples from Mekelle (mean concentration, $146 \mu \mathrm{g} / \mathrm{L}$ ).

Contamination of drinking water with high level of copper may lead to chronic anemia (Acharya et al., 2008). In this study, copper is the only metal that was not detected in all the sampling areas presumably due to the low cupper related industrial and mining activities in the sampling areas. Since the WHO (2008) maximum admissible limit of copper in drinking water was well above the method detection limit; there was no health related risk due to the presence of copper in drinking water of the study areas. 
Table 6. Concentration of heavy metals, $\mathrm{Fe}, \mathrm{Mn}, \mathrm{Ni}, \mathrm{Pb}$ and $\mathrm{Zn}(\mu \mathrm{g} / \mathrm{L})$ in drinking water samples from urban areas of Tigray region, Ethiopia.

\begin{tabular}{|c|c|c|c|c|c|c|c|c|c|c|}
\hline \multirow{2}{*}{$\begin{array}{l}\text { Sampling } \\
\text { location }\end{array}$} & \multicolumn{2}{|c|}{$\mathrm{Fe}$} & \multicolumn{2}{|c|}{$M n$} & \multicolumn{2}{|c|}{$N i$} & \multirow{2}{*}{$\begin{array}{c}P b \\
\bar{X} \pm S D\end{array}$} & \multirow[b]{2}{*}{ Range } & \multicolumn{2}{|c|}{$Z n$} \\
\hline & $\bar{X} \pm S D$ & Range & $\bar{X} \pm S D$ & Range & $\bar{X} \pm S D$ & Range & & & $\overline{\boldsymbol{X}} \pm S D$ & Range \\
\hline Alamata & $\begin{array}{c}311 \pm \\
15\end{array}$ & $\begin{array}{c}298- \\
324\end{array}$ & $\mathrm{BDL}^{*}$ & - & BDL & - & BDL & - & $78 \pm 2$ & $76-80$ \\
\hline Korem & $\begin{array}{c}282 \pm \\
21\end{array}$ & $\begin{array}{c}267- \\
297\end{array}$ & BDL & - & BDL & - & BDL & - & $145 \pm 6$ & $\begin{array}{c}141- \\
149\end{array}$ \\
\hline Maichew & $\begin{array}{c}411 \pm \\
21\end{array}$ & $\begin{array}{c}396- \\
426\end{array}$ & BDL & - & $50 \pm 2$ & $\begin{array}{c}49- \\
52\end{array}$ & $72 \pm 6$ & $68-76$ & $321 \pm 36$ & $\begin{array}{c}296- \\
347\end{array}$ \\
\hline Adigudom & $140 \pm 9$ & $\begin{array}{c}133- \\
146 \\
\end{array}$ & BDL & - & BDL & - & BDL & - & $531 \pm 53$ & $\begin{array}{c}493- \\
569 \\
\end{array}$ \\
\hline Abyi-Adi & $\begin{array}{c}432 \pm \\
60\end{array}$ & $\begin{array}{c}397- \\
501\end{array}$ & BDL & - & $\begin{array}{c}242 \pm \\
212\end{array}$ & $\begin{array}{l}34- \\
459\end{array}$ & $53 \pm 18$ & $41-66$ & $\begin{array}{c}617 \pm \\
117\end{array}$ & $\begin{array}{c}534- \\
700\end{array}$ \\
\hline Hagereselam & $\begin{array}{c}449 \pm \\
205 \\
\end{array}$ & $\begin{array}{c}304- \\
594 \\
\end{array}$ & $\mathrm{BDL}$ & - & BDL & - & BDL & - & $\begin{array}{c}497 \pm \\
136 \\
\end{array}$ & $\begin{array}{c}401- \\
593 \\
\end{array}$ \\
\hline Zalambessa & $\begin{array}{c}121 \pm \\
21\end{array}$ & $\begin{array}{c}106- \\
136\end{array}$ & BDL & - & BDL & - & BDL & - & $\begin{array}{c}306 \pm \\
112\end{array}$ & $\begin{array}{c}226- \\
385\end{array}$ \\
\hline Adigrat & $\begin{array}{c}723 \pm \\
740 \\
\end{array}$ & $\begin{array}{l}104- \\
1872 \\
\end{array}$ & $76 \pm 62$ & $\begin{array}{c}24- \\
156 \\
\end{array}$ & $44 \pm 11$ & $\begin{array}{c}31- \\
63 \\
\end{array}$ & $83 \pm 46$ & $5-136$ & $\begin{array}{c}457 \pm \\
297 \\
\end{array}$ & $\begin{array}{l}71- \\
1050 \\
\end{array}$ \\
\hline Edagahamus & $\begin{array}{c}274 \pm \\
32\end{array}$ & $\begin{array}{c}251- \\
297\end{array}$ & BDL & - & $37 \pm 8$ & $\begin{array}{c}31- \\
42\end{array}$ & $\begin{array}{c}124 \pm \\
78\end{array}$ & $\begin{array}{l}69- \\
179\end{array}$ & $157 \pm 53$ & $\begin{array}{c}119- \\
195\end{array}$ \\
\hline Firewoini & $\begin{array}{c}548 \pm \\
454\end{array}$ & $\begin{array}{c}226- \\
869\end{array}$ & $200 \pm 21$ & $\begin{array}{c}185- \\
215\end{array}$ & $46 \pm 11$ & $\begin{array}{c}38- \\
54\end{array}$ & BDL & - & $\begin{array}{c}428 \pm \\
250\end{array}$ & $\begin{array}{c}251- \\
605\end{array}$ \\
\hline Wukro & $\begin{array}{c}193 \pm \\
72\end{array}$ & $\begin{array}{c}130- \\
304\end{array}$ & BDL & - & $40 \pm 6$ & $\begin{array}{c}34- \\
50\end{array}$ & $59 \pm 20$ & $45-94$ & $\begin{array}{c}404 \pm \\
321 \\
\end{array}$ & $\begin{array}{l}80- \\
904\end{array}$ \\
\hline Mekelle & $\begin{array}{c}379 \pm \\
234\end{array}$ & $\begin{array}{l}97- \\
919\end{array}$ & $34 \pm 4$ & $31-38$ & $37 \pm 6$ & $\begin{array}{c}33- \\
41\end{array}$ & $69 \pm 26$ & $\begin{array}{c}69- \\
106\end{array}$ & $\begin{array}{c}246 \pm \\
186\end{array}$ & $\begin{array}{l}80- \\
583\end{array}$ \\
\hline IndaSelassie & $\begin{array}{c}212 \pm \\
66 \\
\end{array}$ & $\begin{array}{c}134- \\
307 \\
\end{array}$ & $28 \pm 4$ & $25-31$ & BDL & - & $\begin{array}{c}700 \pm \\
916 \\
\end{array}$ & $\begin{array}{l}52- \\
1347 \\
\end{array}$ & $\begin{array}{c}2499 \pm \\
3739 \\
\end{array}$ & $\begin{array}{l}439- \\
5055 \\
\end{array}$ \\
\hline Axum & $\begin{array}{c}218 \pm \\
91 \\
\end{array}$ & $\begin{array}{c}140- \\
434 \\
\end{array}$ & $78 \pm 41$ & $\begin{array}{l}21- \\
124 \\
\end{array}$ & BDL & - & BDL & - & $\begin{array}{c}1338 \pm \\
1456\end{array}$ & $\begin{array}{l}401- \\
3886\end{array}$ \\
\hline Adwa & $\begin{array}{c}271 \pm \\
66 \\
\end{array}$ & $\begin{array}{c}221- \\
345 \\
\end{array}$ & $48 \pm 27$ & $25-77$ & BDL & - & BDL & - & $\begin{array}{c}267 \pm \\
360 \\
\end{array}$ & $\begin{array}{l}45- \\
683 \\
\end{array}$ \\
\hline Enticho & $\begin{array}{c}429 \pm \\
70\end{array}$ & $\begin{array}{c}379- \\
479\end{array}$ & BDL & - & BDL & - & BDL & - & $\begin{array}{c}609 \pm \\
242\end{array}$ & $\begin{array}{c}437- \\
780\end{array}$ \\
\hline
\end{tabular}

${ }^{*} \boldsymbol{B D} \boldsymbol{L}=$ below detection limit of the method.

Iron is the fourth most abundant element by mass in the earth's crust. In water, it occurs mainly in ferrous or ferric state (Ghulman et al., 2008). Iron in surface water generally present is ferric state. It is an essential and non-conservative trace element found in significant concentration in drinking water because of its abundance in the earth's crust. Usually, iron occurring in ground water is in the form of ferric hydroxide, in concentration less than $500 \mu \mathrm{g} / \mathrm{L}$ (Oyeku and Eludoyin, 2010).

The shortage of iron causes disease called "anemia" and prolonged consumption of drinking water with high concentration of iron may lead to liver disease called as haermosiderosis (Rajappa et al., 2010; Bhaskar et al., 2010). In the areas studied, iron content varies from $97 \mu \mathrm{g} / \mathrm{L}$ 
in sample taken from Mekelle to $1872 \mu \mathrm{g} / \mathrm{L}$ from Zalambessa. About $62.69 \%$ of the samples comply the desirable concentration of iron in drinking water $(300 \mathrm{ug} / \mathrm{L})$ set by WHO (2008), whereas $37.31 \%$ of the samples have shown iron concentration above the limit. No guideline is set by WHO (2008) for iron content in drinking water because it is not of health concern at concentrations normally observed in drinking water.

Manganese level varies from below detection in samples from Alamata, Korem, Maichew, Adigudom, Abyi-Adi, Hagereselam, Zalambessa, Edagahamus, Wukro, and Enticho to $215 \mu \mathrm{g} / \mathrm{L}$ from Firewoini. WHOs' (2008) MAL for manganese is $400 \mu \mathrm{g} / \mathrm{L}$ and none of the drinking water samples analyzed show above the limit.

The WHO (2008) MAL for Ni in drinking water is $70 \mu \mathrm{g} / \mathrm{L}$. In this study, Nickel was detected in seven of the sampling areas with concentration range $31 \mu \mathrm{g} / \mathrm{L}$ in water samples from Adigrat and Edagahamus to $459 \mu \mathrm{g} / \mathrm{L}$ from Abyi-Addi. Of the 106 samples analyzed less than 3\% contain Nickel concentration above the WHO (2008) maximum admissible limit (70 $\mu \mathrm{g} / \mathrm{L})$.

Lead is the most significant of all the heavy metals because it is toxic, very common (Gregoriaadou et al., 2001) and harmful even in small amounts. Lead enters the human body in many ways. It can be inhaled in dust from lead paints, or waste gases from leaded gasoline. It is found in trace amounts in various foods, notably in fish, which are heavily subjected to industrial pollution. Some old homes may have lead water pipes, which can then contaminate drinking water. Most of the lead we take is removed from our bodies in urine; however, as exposure to lead is cumulative over time, there is still risk of buildup, particularly in children. Studies on lead are numerous because of its hazardous effects. High concentration of lead in the body can cause death or permanent damage to the central nervous system, the brain, and kidneys (Hanaa et al., 2000). In this study, maximum level of $\mathrm{Pb}(1347 \mu \mathrm{g} / \mathrm{L})$ was found in drinking water sampled from Indasilase and a minimum of BDL in drinking water samples from Alamata, Korem, Adigudom, Hagereselam, Zalambessa, Firewoini, Axum, Adwa and Enticho. More than 70.15\% of the samples (Table 6) analyzed contain lead concentration within the WHO (2008) MAL of lead in drinking water $(10 \mu \mathrm{g} / \mathrm{L})$.

Zinc is one of the important trace elements that play a vital role in the physiological and metabolic process of many organisms. Nevertheless, higher concentrations of zinc can be toxic to the organism (Rajkovic et al., 2008). It plays an important role in protein synthesis and is a metal which shows fairly low concentration in surface water due to its restricted mobility from the 
place of rock weathering or from the natural sources (Rajappa et al., 2010). In this study, a minimum of $45 \mu \mathrm{g} / \mathrm{L}$ and maximum of $5055 \mu \mathrm{g} / \mathrm{L}$ zinc concentration were recorded in water samples from Adwa and Indaselassie respectvely. Although no guideline is set by WHO (2008) for zinc level in drinking water, of the samples analyzed $94.02 \%$ comply the New Zealand standard $(1500 \mu \mathrm{g} / \mathrm{L})$ and $97.01 \%$ of the samples comply the maximum admissible limit set by USEPA (2008), EU (1998), Iranian (1997), Australian (1996) and Indian (2005) standards, table 1 .

Table 7. Percentage of samples which comply with WHO, maximum admissible limit of different drinking water parameters.

\begin{tabular}{lcccccccc}
\hline & \multicolumn{7}{c}{ Drinking water Parameters with $\boldsymbol{M A L}$ set by WHO (2008) } \\
\cline { 2 - 8 } & $\boldsymbol{E C}$ & $\boldsymbol{A s}$ & $\boldsymbol{C d}$ & $\boldsymbol{C r}$ & $\boldsymbol{C u}$ & $\boldsymbol{M n}$ & $\boldsymbol{N i}$ & $\boldsymbol{P b}$ \\
\hline $\begin{array}{l}\text { Percent of samples within } \\
\text { WHO, 2008 MAL. }\end{array}$ & $15.09 \%$ & $59.70 \%$ & $92.54 \%$ & $35.82 \%$ & $100 \%$ & $100 \%$ & $93 \%$ & $70.15 \%$ \\
\hline
\end{tabular}

\section{CONCLUSION}

The main goal of this paper was to assess the status of drinking water quality in urban areas of the Tigray region, northern Ethiopia, with special emphasis on trace heavy metals. A total of 106 drinking water samples were collected from 16 densely populated urban areas of the region. All the samples were analyzed for six physicochemical parameters (T, EC, TDS, salinity, pH, and turbidity) and ten heavy metals ( $\mathrm{As}, \mathrm{Cd}, \mathrm{Co}, \mathrm{Cu}, \mathrm{Cr}, \mathrm{Fe}, \mathrm{Mn}, \mathrm{Ni}, \mathrm{Pb}$, and $\mathrm{Zn}$ ) using standard procedures. The results show that values of electrical conductivity (EC), total dissolved solid (TDS), turbidity and concentrations of some heavy metals ( $\mathrm{As}, \mathrm{Cd}, \mathrm{Cr}, \mathrm{Fe}, \mathrm{Ni}$ and $\mathrm{Pb}$ ) in some of samples, mainly from Adigrat, Edagahamus, Firewoini, Wukro, Mekelle, Axum and Indasilase are higher than the MAL set by WHO, 2008. This is an indication of pollution hazards and weak drinking water treatment practices in these areas which, in turn, have implications on the health of the people.

During the sampling periods, severe drinking water shortage and weak drinking water storage practices (especially small service giving enterprises like hotels, restaurants and cafeteria) have also been observed. In some areas, very old metal tankers which may stay for over six months without cleaning were used to store drinking water and in other areas mainly in households, tankers made from plastic and clay without covers and necessary cleanups were used to store drinking water. All this together enhance the risk on human health. 
This study, therefore, recommends the government and other responsible authorities to: (1) introduce relevant drinking water treatment techniques which can reduce the current levels of heavy metals, (2) Prevent any kind of waste disposal into rivers, canals or any reservoirs that supply domestic drinking water (3) educate the people to have better drinking water storage practices, and (4) support further study to be conducted on other physical, chemical and biological parameters of significant health concern and on identification of potential sources of the contaminants including heavy metal contaminants.

\section{ACKNOWLEDGEMENTS}

The project was financed by Mekelle University recurrent budget (Ref. No. CNCS/RB/09/09) and the authors are grateful for the financial support of Mekelle University, Ethiopia. The authors would also like to appreciate $\mathrm{Mr}$ Teame Kiros, research assistant in Aquatic chemistry Laboratory of MU-ACL, for providing the necessary facilities and technical support. Appreciations shall also goes to Municipality and water resource offices of the study areas, Water and Energy Bureau of Tigray, Health Bureau of Tigray, Analytical Laboratory of Ezana Mining Development P.L.C., and Addis Ababa University, Department of Chemistry for the support they offer for the successful completion of the project.

\section{REFERENCES}

Acharya, G.D., Hathi, M.V., Patel, A.D \& Parmar, K.C. 2008. Chemical properties of groundwater in Bailoda Taluka region, north Gujarat, India, viewed 23 June, 2010, $<$ http://www.e-journals.in/PDF/V5N4/792-796.pdf $>$.

Akoto, O \& Adiyiah, J. 2007. Chemical analysis of drinking water from some communities in the brong ahafo region. International Journal of Environmental Science and Technology, 4(2):211-214.

Anawara, H.M., Akaib, J., Mostofac, K.M.G., Safiullahd, S \& Tareqd, S.M. 2002. Arsenic poisoning in groundwater- health risk and geochemical sources in Bangladesh. Environ. Int., 27:597-604.

Anonymous, 1992. Report on UN Conf. on Environ. and Development,. A/CONF. 151/26.,1, 277

Atalay, A., Pao, S., James, M., Whitehead, B \& Allen, A. 2008. Drinking water assessment at 
underserved farms in Virginia's coastal plain. Journal of Environmental Monitoring and Restoration, 4:53-64.

Bhaskar, C.V., Kumar, K \& Nagendrappa, G. 2010. Assessment of heavy metals in water samples of certain locations situated around Tumkur, Karnataka, India', viewed 12 June, 2010, <http://www.indiaenvironmentportal.org.in/.../Assessment\%20of\%20heavy\%20m etals\%20in\%20water\%20samples.pdf $>$.

Bishnoi, M \& Arora, S. 2007. Potable ground water quality in some villages of Haryana, India: focus on fluoride. Journal of Environmental Biology, 28(2): 291-294.

Danamark.com. 2008, Heavy metals in drinking water, viewed August 1, 2010, $<$ http://www.danamark.com/Heavymetalsindrinking water/pdf $>$.

Ghaedi, M., Fathi, M.R., Marahel, F \& Ahmadi, F. 2005. Simultaneous preconcentration and determination of copper, nickel, cobalt and lead ions content by fame atomic absorption spectrometry. Fresen. Environ. Bull.,14:1158-1165.

Ghulman, B.A., EL-Bisy, M.S \& Ali, H. 2008. Ground water assessement of makkah almokarama. Proceedings of the 12th International Water Technology Conference, Umm Al-Qura University, Makkah, pp. 1515-1527.

Gregoriadou, A., Delidou, K., Dermosonoglou, D., Tsoumparis, P., Edipidi, C \& Katsougiannopoulos, B. 2001. Heavy metals in drinking water in Thessaloniki area, Greece. Proceedings of the 7th International Conference on Environmental Science and technology, Aristotle University, Ermoupolis.

Hanaa, M., Eweida, A \& Farag, A. 2000. Heavy metals in drinking water and their environmental impact on human health. International Conference on Environmental Hazards Mitigation, Cairo University, Egypt, pp. 542-556.

Jayana, B.L., Prasai, T., Singh, A \& Yami, K.D. 2009. Assessment of drinking water quality of madhyapur-thimi and study of antibiotic sensitivity against bacterial isolates. Nepal Journal of Science and Technology, 10:167-172.

Kar, D., Sur, P., Mandal, S.K., Saha, T \& Kole, R.K. 2008. Assessment of heavy metal pollution in surface waters. International Journal of Environmental Science and Technology, 5(1): 119-124.

London, L., Dalvie, M.A., Nowicki, A \& Cairncross, E. 2005. Approaches for regulating water in South Africa for the presence of pesticides. Water SA, 31(1):53-60. 
Momodu, M.A \& Anyakpra, C.A. 2010. Heavy metal contamination of ground awter: the surulere study. Research Journal of Environmental and Earth Science, 2(1):39-43.

Nassef, M., Hannigan, R., EL Sayed, K.A \& Tahawy, M.S.El. 2006. Determination of some heavy metals in the environment of Sadat industrial city. Proceeding of the 2nd Environmental Physics Conference, Cairo University, Egypt, pp. 145-152.

Oguntoke, O., Aboderin, O.J \& Bankole, A.M. 2009. Association of water-borne diseases morbidity pattern and water quality in parts of Ibadan City, Nigeria. Tanzania Journal of Health Research, 11(4):189-195.

Orebiyi, E.O., Awomeso, J.A., Idowu, O.A., Martins, O., Oguntoke \& Taiwo, A.M. 2010. Assessment of pollution hazards of shallow well water in Abeokuta and environs, southwest, Nigeria. American Journal of Environmental Science, 6(1):50-56.

Oyeku, O.T \& Eludoyin, A.O. 2010. Heavy metal contamination of ground water resources in a Nigerian urban settlement. African Journal of Environmental Science and Technology, 4(4):201-214.

Pandey, J., Shubhashish, K \& Pandey, R. 2010. Heavy metal contamination of Ganga river at Varanasi in relation to atmospheric deposition. Tropical Ecology, 51(2):365-373.

Rajappa, B., Manjappa, S \& Puttaiah, E.T. 2010. Monitoring of heavy metal concentration in groundwater of Hakinaka Taluk, India. Contemporary Engineering Sciences, 3(4):183190.

Rajkovic, M.B., Lacnjevac, C.M., Ralevic, N.R., Stojanovic, M.D., Toskovic, D.V., Pantelic, G.K., Ristic, N.M \& Jovanic, S. 2008. Identification of metals (heavy and radioactive) in drinking water by indirect analysis method based on scale tests. Sensors, 8:2188-2207.

Reimann, C, Bjorvatn, K., Frengstad, B., Melaku, Z., Teklehaimanot, R \& Siewers, U. 2003. Drinking water quality in the Ethiopian section of the east African rift valley I - data and health aspects. The Science of Total Environment, 311:65-80.

Sanayei, Y., Ismail, N \& Talebi, S.M. 2009. Determination of heavy metals in Zayandeh rood, Isfahan-Iran. World Applied Sciences Journal, 6(9):1209-1214.

Singh, S \& Mosley, L.M. 2003. Trace metal levels in drinking water on Viti Levu, Fiji Islands. S. Pac. J. Nat. Sci., 21:31- 34.

Tuzen, M \& Soylak, M. 2006. Evaluation of metal levels of drinking waters from the Tokatblack sea region of Turkey. Polish Journal of Environmental Study, 15(6):915-919. 
TWAS. 2002. Safe drinking water-the need, the problem, solutions and an action plan, Third world academy of sciences, Trieste, Italy.

WHO 2008, Guidelines for drinking water quality, World Health Organization, Geneva.

WHO 1998, European standard for drinking water, World Health Organization, Geneva. 